\title{
LP-BM5 virus-infected mice produce activating autoantibodies to the AMPA receptor
}

\author{
Elena Koustova, ${ }^{1}$ Yoshitatsu Sei, ${ }^{2}$ Linda Fossom, ${ }^{1}$ Mei-Ling Wei ${ }^{3}$ Peter N.R. Usherwood, ${ }^{3}$ \\ N. Bradley Keele, ${ }^{3}$ Michael A. Rogawski, ${ }^{3}$ and Anthony S. Basile ${ }^{1}$ \\ ${ }^{1}$ Laboratory of Bioorganic Chemistry, National Institute of Diabetes and Digestive and Kidney Diseases, \\ NIH, Bethesda, Maryland, USA \\ ${ }^{2}$ Department of Anesthesiology, Uniformed Services University of the Health Sciences, Bethesda, Maryland, USA \\ ${ }^{3}$ Epilepsy Research Branch, National Institute of Neurological Disorders and Stroke, NIH, Bethesda, Maryland, USA \\ Address correspondence to: Anthony S. Basile, Laboratory of Bioorganic Chemistry, Building 8, Room 121, \\ MSC 0826, National Institute of Diabetes and Digestive and Kidney Diseases, NIH, Bethesda, Maryland 20892-0008, USA. \\ Phone: (301) 496-4071; Fax: (301) 402-0008; E-mail: asbasile@helix.nih.gov.
}

Received for publication October 6, 2000, and accepted in revised form February 5, 2001.

Autoantibodies to $\alpha$-amino-3-hydroxy-5-methylisoxazole-4-propionic acid (AMPA) receptors may contribute to chronic hyperexcitability syndromes and neurodegeneration, but their origin is unclear. We examined LP-BM5 murine leukemia virus-infected mice, which manifest excitotoxic brain lesions and hypergammaglobulinemia, for the presence of AMPA-receptor Ab's. Endogenous IgG accumulated upon neurons in the neocortex and caudate/putamen of infected mice and interacted with native and recombinant AMPA-receptor subunits with the following relative abundance: GluR3 $\geq$ GluR1 > GluR2 = GluR4, as determined by immunoprecipitation. In a radioligand assay, IgG preparations from infected mice specifically inhibited $\left[{ }^{3} \mathrm{H}\right]$ AMPA binding to receptors in brain homogenates, an activity that was lost after preadsorbing the IgG preparation to immobilized LP-BM5 virus. These IgGs also evoked currents when applied to hippocampal pyramidal neurons or to damaged cerebellar granule neurons. These currents could be blocked using any of several AMPA receptor antagonists. Thus, anti-AMPAreceptor Ab's can be produced as the result of a virus infection, in part through molecular mimicry. These Ab's may alter neuronal signaling and contribute to the neurodegeneration observed in these mice, actions that may be curtailed by the use of AMPA-receptor antagonists.

J. Clin. Invest. 107:737-744 (2001).

\section{Introduction}

Abnormalities in self-recognition by the immune system give rise to a number of chronic neurological diseases (1-4). Recent reports indicate that Ab's to $\alpha$-amino-3hydroxy-5-methylisoxazole-4-propionic acid-receptor (AMPA-receptor) subunits are present in the plasma and brain in Rasmussen's encephalitis (5) and nonfamilial olivopontocerebellar atrophy (6). Along with the kainate (KA) and $N$-methyl-D-aspartate (NMDA) receptors, AMPA receptors are members of the family of glutamategated ion channels and play a critical role in mediating fast excitatory neurotransmission (7). AMPA receptors are heteromeric tetramers consisting of the subunits GluR1-4 and are $\mathrm{Ca}^{++}$permeable when lacking the edited GluR2 subunit (7). The interaction of Ab's with AMPA-receptor subunits may activate the receptor, altering synaptic transmission. Chronic activation of the receptors may lead to neuronal excitotoxicity, contributing to the manifestations of these syndromes $(5,6,8)$.

While autoimmune processes may play a role in some chronic neurodegenerative diseases, the mechanisms by which these and other autoimmune syndromes arise vary considerably and include: molecular mimicry of microbial proteins (9); loss of immunotolerance (1); epitope spreading; and panactivation of $\mathrm{T}$ - and $\mathrm{B}$-cell clones, resulting in the production of a variety of Ab's, some of which are fortuitously anti-self (10). Moreover, the mechanism(s) responsible for initiating the loss of tolerance in autoimmune neurological diseases remains unclear. Animal models of these syndromes typically require the administration of an adjuvant and a specific protein resembling the self-protein. Such models include experimental autoimmune encephalomyelitis induced by the administration of myelin proteolipid apoprotein (2) or immunization with an AMPA receptor-fragment fusion protein to produce syndromes resembling Rasmussen's encephalitis (5). However, an animal model that produces anti-self Ab's in association with a disease state may allow better understanding of the processes giving rise to $A b$ 's causing autoimmune neurological disorders.

One potential model is the LP-BM5 murine leukemia virus-infected C57BL/6 mouse. These mice develop a severe immunodeficiency manifested by a number of functional and phenotypic changes in leukocyte populations (11), including T- and B-cell anergy, polyclonal B-cell activation, and hypergammaglobulinemia. Central nervous system (CNS) damage and cognitive deficits develop concurrently with the immunodeficiency and are manifested as spatial learning and memory defects $(12,13)$ with global glial activation $(11)$, synaptic loss (13), neurotransmitter depletion (14), and decreases in AMPA-receptor density (15). The decrease 

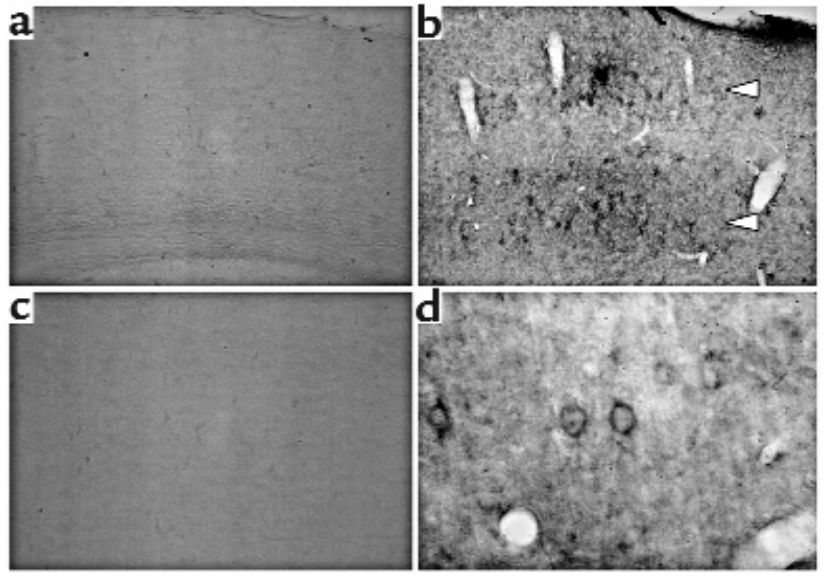

Figure 1

IgG accumulates on cortical neurons in LP-BM5-infected mice. Sections were cut from the brains of control mice ( $\mathbf{a}$ and $\mathbf{c}$ ) and mice 12 weeks after inoculation with LP-BM5 ( $\mathbf{b}$ and $\mathbf{d}$ ), then stained with HRP-conjugated goat anti-mouse IgG (1:250). IgG was distributed throughout the brain, with localized accumulations around neurons in layers II-III and V of the parietal cortex (b) (arrowheads). Closer examination reveals higher densities of IgG outside the somatic membrane of cortical neurons $(\mathbf{d})$. ( $\mathbf{a}$ and b) $\times 100$; (c and d) $\times 630$.

in AMPA-receptor density, combined with the loss of synapses and the concurrent behavioral abnormalities, suggests that neuronal signal processing is substantially compromised in LP-BM5-infected mice.

While the CNS damage observed in these mice is consistent with a chronic excitotoxic lesion (14), the excitotoxins involved have not been completely identified. Given the existence of activating anti-AMPA-receptor $A b$ 's in patients with chronic neurodegenerative diseases $(5,6)$ and the hypergammaglobulinemia (16) and loss of GluR3 subunits observed in LP-BM5-infected mice (15), we have investigated these mice to determine if they produce anti-AMPA-receptor Ab's as part of their infection and to delineate the role of these Ab's in chronic neurodegeneration.

\section{Materials}

Animal preparation and IgG purification. Male mice were housed and fed according to NIH Association for the Assessment and Accreditation of Laboratory Animal Care guidelines, and inoculated intraperitoneally at 4-6 weeks of age with LP-BM5 MuLV stocks. LPBM5-infected (8-10 weeks after inoculation) and control (uninfected littermate) C57BL/6 mice were used, as well as LP-BM5-infected DBA2/J and ecotropic virus-infected C57BL/6 mice.

Infected and control mice were anesthetized (80 $\mathrm{mg} / \mathrm{kg}$ pentobarbital), bled, then perfused with heparinized PBS $\left(0-4^{\circ} \mathrm{C}\right)$. The brains were homogenized in $0.32 \mathrm{M}$ sucrose $/ 10 \mathrm{mM}$ Tris $\mathrm{HCl}, \mathrm{pH} 7.4$, then centrifuged at 40,000 $\mathrm{g}$ for 20 minutes. An equal volume of binding buffer (Pierce Chemical Co., Rockford, Illinois, USA) was added to serum or brain supernatants, filtered, then applied to immobilized protein
A/G affinity columns (Pierce Chemical Co.). IgG was eluted from the columns according to the package instructions. The eluates were desalted on $30 \mathrm{ml} \mathrm{dex-}$ tran columns (Pierce Chemical Co.), pooled, and concentrated with $50-\mathrm{kDa}$ exclusion centrifugal filters (Millipore Corp., Bedford, Massachusetts, USA) to yield similar IgG protein concentrations. Some IgG isolates were prepared using thiotropic gel-affinity chromatography (Pierce Chemical Co.).

Total and IgG protein concentrations were determined using bicinchoninic acid and mouse IgG assay kits (Pierce Chemical Co.). The purity of IgG prepared from LP-BM5 brains using new protein A/G columns was approximately $88 \%(140 \pm 26 \mathrm{ng} / \mu \mathrm{IgG}, 160 \pm 47 \mathrm{ng} / \mu \mathrm{l}$ total protein; $n=5)$ for brain, 93\% (270 $\pm 30 \mathrm{ng} / \mu \mathrm{lgG}$, $290 \pm 43 \mathrm{ng} / \mu \mathrm{l}$ total protein; $n=4$ ) for serum. Brain IgG extracts prepared with T-gel columns were of lower purity (IgG protein: $79 \pm 8 \mathrm{ng} / \mu \mathrm{l}$; total protein: $260 \pm 92$ $\mathrm{ng} / \mu \mathrm{l})$. Free glutamate levels were measured in $\mathrm{IgG}$ extracts using $o$-phthaldialdehyde derivatization, followed by separation using reverse-phase HPLC with fluorescence detection (17). Histology of IgG binding within the brain was performed using peroxidase-conjugated anti-mouse IgG F(ab') fragments (1:250; Sigma Chemical Co., St. Louis, Missouri, USA) (13).

Immunoprecipitation. Brain tissue (40 $\mathrm{mg}$ ) was homogenized in $300 \mu$ l of TNESV buffer $(50 \mathrm{mM}$ Tris- $\mathrm{HCl}, \mathrm{pH} 7.6$, $100 \mathrm{mM} \mathrm{NaCl}, 1 \%$ NP40, 2 mM EDTA, 1 mM sodium orthovanadate, $10 \mathrm{mM}$ AEBSF, $100 \mathrm{mg} / \mathrm{ml}$ leupeptin, and $20 \mathrm{mg} / \mathrm{ml}$ aprotinin) at $0-4{ }^{\circ} \mathrm{C}$. The samples were centrifuged and supernatant aliquots $(150 \mu \mathrm{g}$ protein) were incubated $\left(1\right.$ hour, $\left.0-4^{\circ} \mathrm{C}\right)$ with $5.6 \mathrm{mg}$ of protein $\mathrm{A}$ beads (Pierce Chemical Co.) in TNESV buffer $(500 \mu \mathrm{l})$. Unprecipitated protein samples $(15 \mu \mathrm{g})$ were directly immunoblotted to determine the quantity and quality of the target proteins. Alternatively, mouse IgG preparations $(6-8 \mu \mathrm{g}$ of IgG protein) or commercially available Ab's to GluR1, 2, $2 / 3$, or 4 (Chemicon International, Temecula, California, USA) were incubated with protein $\mathrm{A} / \mathrm{G}$ beads (Pierce Chemical Co.). After extensive washing, recombinant GluR subunits were added to the incubation mixture. These subunits were expressed in HEK 293 cells transfected with plasmids containing genes for either GluR1, 2, 3, or 4 (5 $\mathrm{g}$ DNA) using FuGENE 6 (Roche Molecular Biochemicals, Indianapolis, Indiana, USA). The recombinant GluR preparations or untransfected HEK cells (40 $\mu \mathrm{g}$ protein) were incubated with the bead-coupled Ab's (24 hours, $\left.0-4^{\circ} \mathrm{C}\right)$, then washed. After immunoprecipitation, beads were boiled in Laemmli buffer, the supernatant subjected to SDS-PAGE, and blotted (15) with Ab's to the appropriate subunit $(\alpha$ GluR1, 1:200; $\alpha$ GluR2, 2/3, 1:1000; Chemicon International).

LP-BM5 virus or ecotropic virus stocks, or uninfected SC-1 cells, were used to assess IgG interaction with viral proteins. The cell preparations were concentrated (10-kDa exclusion centrifugal filters; Millipore Corp.), aliquots $(25 \mu \mathrm{g}$ protein) were applied to PVDF membranes in a microdot apparatus (Bio-Rad Laboratories, Hercules, California, USA), and they were incubated 2 
hours. The dots were washed, blocked, and incubated with IgG preparations $(50 \mu \mathrm{l})$ or antiecotropic virus $\mathrm{Ab}$ (1:200) overnight $\left(0-4^{\circ} \mathrm{C}\right)$, then washed, incubated with horseradish-peroxidase-conjugated (HRP-conjugated) goat anti-mouse or goat anti-rabbit IgG, and visualized with film. Virus was also immobilized to $5 \times$ 10-mm PVDF strips, washed, blocked, then incubated with $500 \mu \mathrm{l}$ of brain IgG isolates. Aliquots were then added to $\left[{ }^{3} \mathrm{H}\right]$ AMPA-binding assays.

Radioligand-binding assays. Washed mouse cortex homogenates (15) were resuspended in: 50 vol. of 30 $\mathrm{mM}$ Tris $\mathrm{HCl}$ buffer, $2.5 \mathrm{mM} \mathrm{CaCl}_{2}, 100 \mathrm{mM} \mathrm{KSCN}$ ([ $\left.{ }^{3} \mathrm{H}\right]$ AMPA assay); 20 vol. of $20 \mathrm{mM}$ HEPES, $120 \mathrm{mM}$ $\mathrm{NaCl}, 2 \mathrm{mM} \mathrm{CaCl}_{2}, 5 \mathrm{mM} \mathrm{KCl}, 1 \mathrm{mM} \mathrm{MgCl} 2\left(\left[{ }^{3} \mathrm{H}\right]\right.$ nicotine); or 10 vol. $50 \mathrm{mM}$ Tris citrate $\left(\left[{ }^{3} \mathrm{H}\right]\right.$ cis-4-(phosphonomethyl)piperidine-2-carboxylic acid $\left(\left[{ }^{3} \mathrm{H}\right] \mathrm{CGS}\right.$ 19755)), $\left[{ }^{3} \mathrm{H}\right] \mathrm{KA},\left[{ }^{3} \mathrm{H}\right]$ flunitrazepam, $\left[{ }^{3} \mathrm{H}\right]$ muscimol, and $\left[{ }^{3} \mathrm{H}\right]$ dizocilpine). AMPA $(0.5 \mu \mathrm{M})$ was added to the $\left[{ }^{3} \mathrm{H}\right] \mathrm{KA}$ competition assays to suppress radioligand binding to the AMPA receptors. All assays were performed in duplicate by incubating $25-\mu \mathrm{l}$ aliquots of brain homogenate with $0-50 \mu \mathrm{l}$ of assay buffer and 1to $50-\mu \mathrm{l}$ aliquots of $\operatorname{IgG}$ preparation $\left(2\right.$ hours, $0-4^{\circ} \mathrm{C}$ ) before adding $25 \mu \mathrm{l}$ of radioligand ( $\left[{ }^{3} \mathrm{H}\right] \mathrm{AMPA}, 25 \mathrm{nM}$; $\left[{ }^{3} \mathrm{H}\right]$ dizocilpine, $5 \mathrm{nM} ;\left[{ }^{3} \mathrm{H}\right] \mathrm{CGS} 19755,50 \mathrm{nM} ;\left[{ }^{3} \mathrm{H}\right] \mathrm{KA}$, $7 \mathrm{nM} ;\left[{ }^{3} \mathrm{H}\right]$ muscimol, $30 \mathrm{nM}$; $\left.{ }^{3} \mathrm{H}\right]$ flunitrazepam, $1 \mathrm{nM}$; $\left[{ }^{3} \mathrm{H}\right]$ nicotine, $\left.2 \mathrm{nM}\right)$. Nonspecific binding was determined in the presence of $10 \mathrm{mM}$ glutamate $\left(\left[{ }^{3} \mathrm{H}\right]\right.$ AMPA, $\left[{ }^{3} \mathrm{H}\right] \mathrm{CGS}$ 19755, $\left.\left[{ }^{3} \mathrm{H}\right] \mathrm{KA}\right) ; 10 \mu \mathrm{M}$ phencyclidine ([$\left.{ }^{3} \mathrm{H}\right]$ dizocilpine); $10 \mu \mathrm{M}$ flumazenil $\left(\left[{ }^{3} \mathrm{H}\right]\right.$ flunitrazepam); $1 \mathrm{mM}$ GABA $\left(\left[{ }^{3} \mathrm{H}\right]\right.$ muscimol); or $10 \mu \mathrm{M}$ nicotine $\left(\left[{ }^{3} \mathrm{H}\right]\right.$ nicotine $)$. The assays were incubated an additional $1-2$ hours at $0-4^{\circ} \mathrm{C}$ (except CGS 19755 , which was incubated for 30 minutes at $25^{\circ} \mathrm{C}$ ), terminated by rapid filtration, and counted. $\left[{ }^{3} \mathrm{H}\right] \mathrm{AMPA}$ (2.5-800 $\mathrm{nM})$ was used to define AMPA receptors in saturation assays. The equilibrium-binding constants for all assays were determined using nonlinear regression (Prism II; GraphPad Software for Science Inc., San Diego, California, USA).
Electrophysiology. Primary cultures of rat hippocampal neurons were prepared $(18,19)$, and recordings made $\left(25^{\circ} \mathrm{C}\right)$ on neurons cultured $10-14$ days. Before each experiment, culture media was replaced with external recording solution $(140 \mathrm{mM} \mathrm{NaCl} ; 5 \mathrm{mM} \mathrm{KCl} ; 0.1 \mathrm{mM}$ $\mathrm{CaCl}_{2} ; 10$ mM HEPES; pH 7.4, 320 mOsm/kg) supplemented with tetrodotoxin (TTX; $1 \mu \mathrm{M}$ ), aminophosphonovalerate (APV; $100 \mu \mathrm{M})$, and strychnine $(1 \mu \mathrm{M})$. Hippocampal neurons were used for experimentation if the membrane potential $(\leq 60 \mathrm{mV})$ was achieved without current injection. All experiments were conducted from a holding potential of $-70 \mathrm{mV}$.

Control and test solutions were applied through a gravity-fed, multibarrel, rapid-perfusion system $(18,19)$ positioned $200 \mu \mathrm{m}$ from the neuron. Neurons were constantly bathed with either control or test solutions, and only one valve was opened at a time. Clampfit (pCLAMP software; Axon Instruments Inc., Burlingame, California, USA) was used to measure peak current amplitudes and calculate the evoked-current $10-90 \%$ rise time and single exponential time constant $(\tau)$.

In vitro cytotoxicity. Primary cultures of granule neurons were prepared from cerebella of 8-day-old Sprague-Dawley rat pups (20). On the day of testing, the medium was removed, the cells rinsed twice and replaced with Locke's solution, containing cyclothiazide $(50 \mu \mathrm{M})$, dizocilpine $(10 \mu \mathrm{M})$, 1,2,3,4-tetrahydro-6-nitro-2,3-dioxo-benzo[f] quinoxaline-7-sulfonamide (NBQX; $10 \mu \mathrm{M})$, AMPA (100 $\mathrm{nM}$ to $100 \mu \mathrm{M})$, or IgG preparation $(1-1000 \mathrm{ng} / 500 \mu \mathrm{l})$. The cells were incubated in these solutions for 21 hours, after which $25-\mu \mathrm{l}$ aliquots were removed for measurement of lactate dehydrogenase (LDH) activity (Promega Corp., Madison, Wisconsin, USA). The OD values derived from the LDH assay were normalized to the percentage of granule neurons killed based upon standard curves for glutamate-induced neuron death and LDH release. Approximately $10 \%$ of the granule neurons were dead in the absence of any treatment, while addition of $100 \mu \mathrm{M}$ glutamate killed approximately $80 \%$ of the neurons as determined by trypan blue staining and manual count-

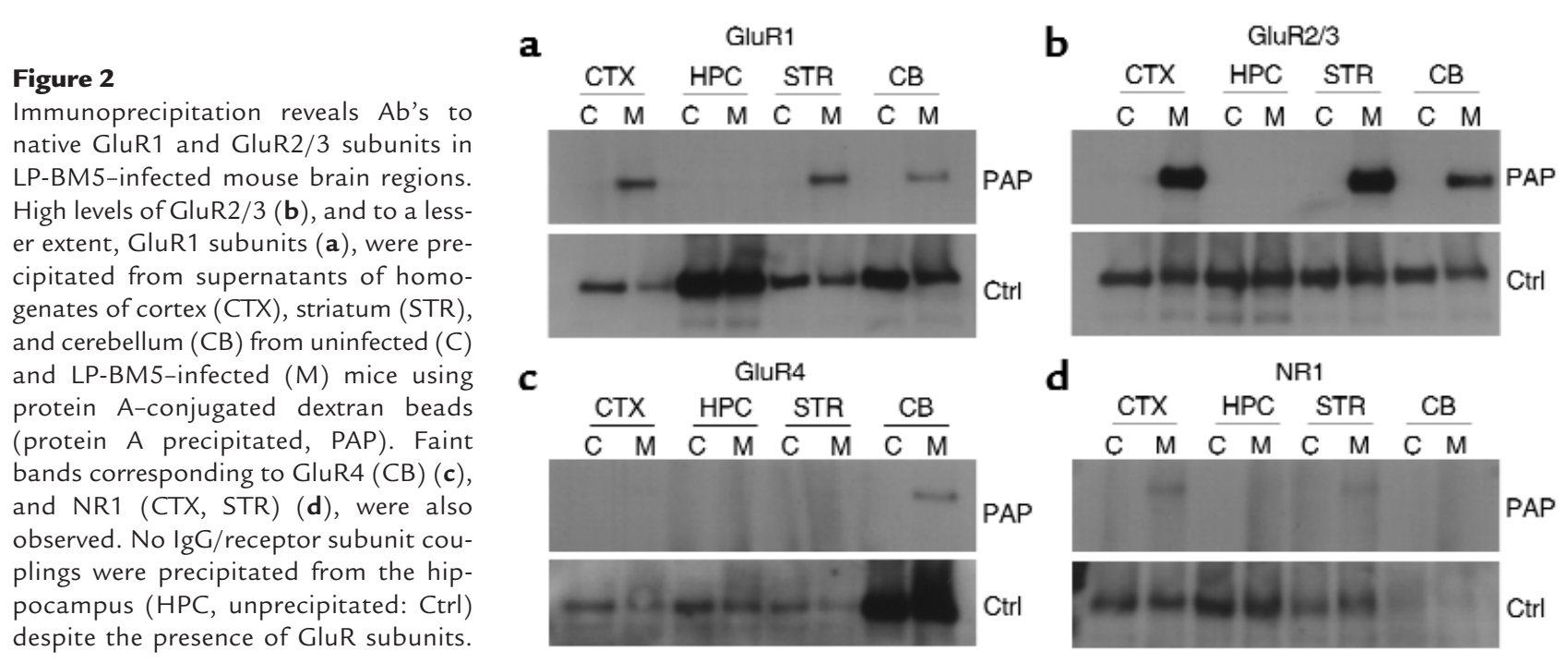




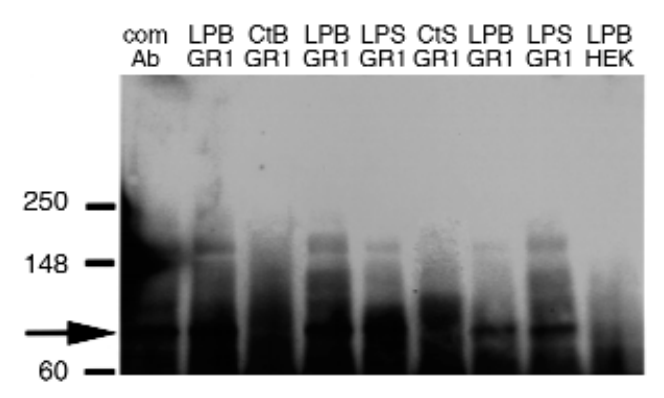

com LPB CtB LPB LPS CtS LPB LPS LPB Ab GR2 GR2 GR2 GR2 GR2 GR2 GR2 HEK
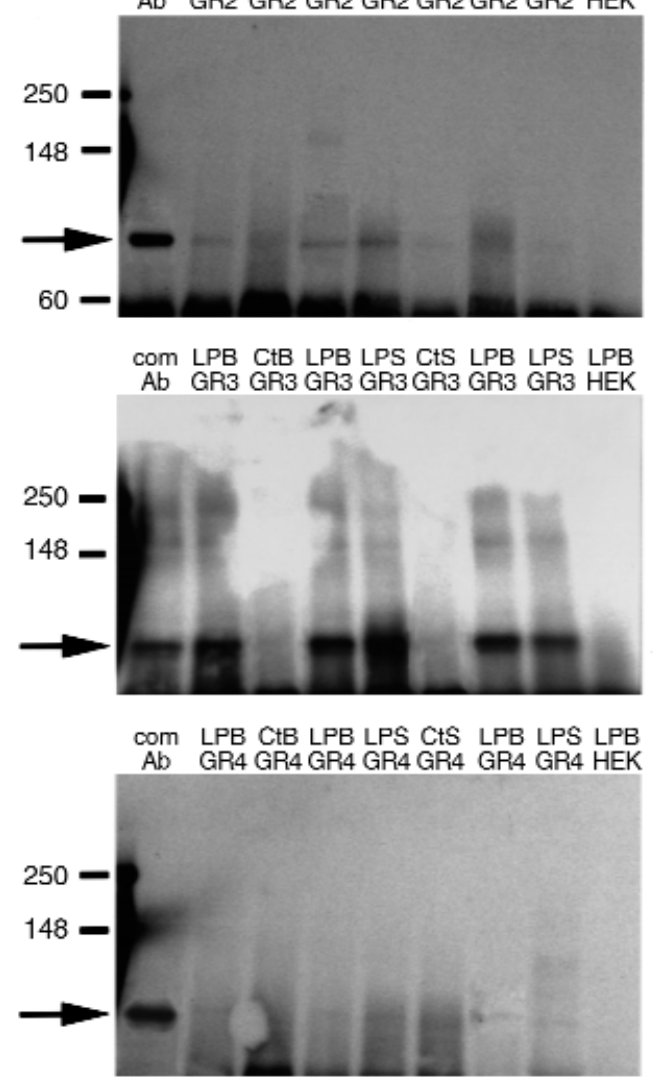

\section{Figure 3}

Immunoprecipitation using recombinant AMPA-receptor subunits indicates LP-BM5 brain IgG is specific for GluR1 and GluR3. IgG preparations from infected and uninfected mouse brain ( $\mathrm{LPB}, \mathrm{CtB}$ ) and serum (LPS, CS), as well as commercially available Ab's to GluR1, 2,3 , and 4 (lane 1, com $A b$ ), were coupled to protein $A / G$ beads, then incubated with recombinant GluR1 (GR1) (a), GluR2 (GR2) (b), GluR3 (GR3) (c), and GluR4 (GR4) (d) subunits. The last lane is an immunoprecipitation using LP-BM5 IgG (as in lane 4) with untransfected HEK cell membranes. Numbers on left represent the molecular weights of the protein standards, with the large arrow at approximately $100 \mathrm{kDa}$ indicating the position of the GluR protein band.

ing (20). For complement assays, guinea pig complement serum or C4-depleted serum (Sigma Chemical Co.) was added to each well at a dilution of 1:20.

\section{Results}

LP-BM5-infected mice develop a profound hypergammaglobulinemia (16), with regionally intense accumulations of IgG-positive immunoreactivity on the plasma membranes of neurons in the caudate/putamen and layers III and IV of the cerebral cortex (Figure 1). Immunoprecipitations of IgG-protein complexes from LPBM5-infected mouse (LP-BM5) brain homogenates indicated the presence of $\operatorname{IgG}$ from the cortex and striatum that strongly interacted with GluR2/3 subunits (Figure $2 \mathrm{~b}$ ), followed by GluR1 (Figure 2a). IgG from the cerebellum interacted with GluR4 subunits (Figure 2c). IgG from cortex and striatum also showed weak interactions with NR1 subunits (Figure 2d). Immunoprecipitations using IgG prepared from LP-BM5 brains and recombinant GluR subunits showed strong $\mathrm{Ab}$ interactions with GluR3 (Figure 3c), weaker interactions with GluR1 (Figure $3 \mathrm{a}$ ), and much attenuated binding to GluR2 (Figure 3 b) and GluR4 subunits (Figure 3d). Immunoprecipitations using control brain IgG preparations showed no discrete protein bands at approximately $100 \mathrm{kDa}$ for any of GluR subunits. Ab's against GluR1 were found in 17 of $33 \mathrm{IgG}$ preparations tested, while 6 of 13 contained Ab's to GluR2, 14 of 33 to GluR3, and 7 of 13 to GluR4. Twelve extracts reacted with a single subunit, seven interacted with two subunits, three interacted with three subunits, and one extract interacted with all four subunits. $\mathrm{IgG}$ prepared from the serum of $\mathrm{C} 57 \mathrm{BL} / 6$ mice infected with the nonpathogenic, ecotropic virus component of LP-BM5 and from infection-resistant DBA2/J mice inoculated with LP-BM5 showed no interaction with immunoblots of GluR subunits.

The specificity of LP-BM5 IgG for ionotropic neurotransmitter receptors was further investigated using radioligand receptor-binding assays. LP-BM5 brain IgG preparations (1-50 $\mu \mathrm{l}$ containing $50-7,000 \mathrm{ng}$ IgG protein) inhibited $\left[{ }^{3} \mathrm{H}\right]$ AMPA binding to mouse cerebral cortex membranes (Figure 4a). $\left[{ }^{3} \mathrm{H}\right]$ AMPA binds preferentially to AMPA receptors, which are expressed in high density in the neocortex, but has low affinity for other ionotropic glutamate receptors. This inhibition was observed regardless of whether the LP-BM5 brain IgG was prepared using thiotropic (Figure 4a, Table 1) or protein $\mathrm{A} / \mathrm{G}$ columns. Because of the greater potency and purity of $\operatorname{IgG}$ isolates made with protein $A / G$ columns (see Methods), this technique was used for all subsequent IgG preparations. $\left[{ }^{3} \mathrm{H}\right] \mathrm{AMPA}$ binding was inhibited with similar efficacy by LP-BM5 serum IgG, albeit with sixfold lower potency (Figure 4a, Table 1). IgG prepared from control mouse brain or serum inhibited [ $\left.{ }^{3} \mathrm{H}\right]$ AMPA binding with low potency and incomplete efficacy. The glutamate concentration in IgG preparations of control $(n=3)$ and LP-BM5-infected $(n=6)$ brain extracts was below the limit of assay sensitivity $(\sim 100 \mathrm{nM})$. The inhibition of [ $\left.{ }^{3} \mathrm{H}\right]$ AMPA binding by LP-BM5 brain IgG $(0.06 \pm 0.02 \mathrm{ng}$ $\mathrm{IgG} /$ assay, $56 \pm 4.2 \%$ inhibition; $n=4$ ) was blocked by boiling the preparation before adding it to the binding assay $(93 \pm 5.8 \% ; n=4, P<0.05$, paired $t$ test).

The interaction of infected mouse brain IgG with the AMPA receptor was further characterized using saturation-binding assays. The binding of [ $\left.{ }^{3} \mathrm{H}\right]$ AMPA to AMPA receptors is characterized by high- and low-affinity binding sites (15) that may be influenced independently by 


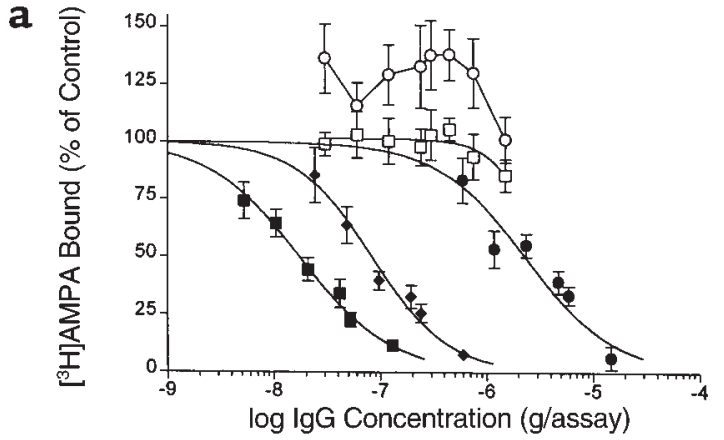

b

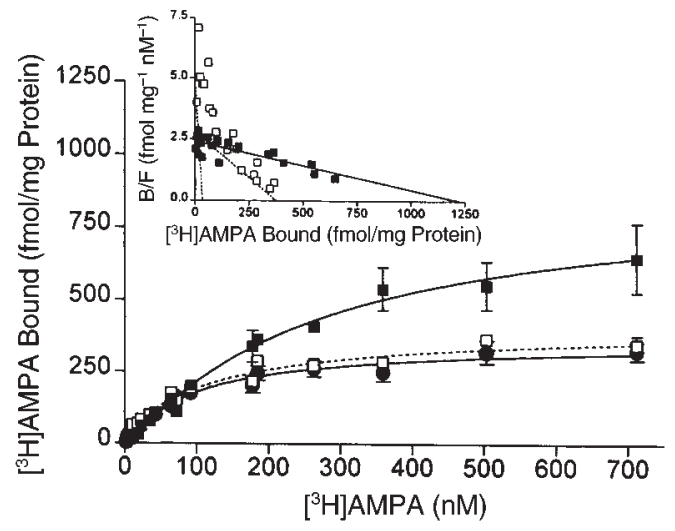

Figure 4

LP-BM5 mouse brain IgG modulates $\left[{ }^{3} \mathrm{H}\right]$ AMPA binding. (a) IgG from LP-BM5 brain (protein A/G, filled squares; T-gel column, filled diamonds) or serum (protein $A / G$, filled circles), or control mouse brain (protein $A / G$, open squares), or serum (protein $A / G$, open circles) were added to a competition assay for [ $\left.{ }^{3} \mathrm{H}\right] \mathrm{AMPA}$. Curves represent data from a single assay performed in triplicate. (b) An IC 50 volume of infected mouse brain IgG (filled squares) inhibited $\left[{ }^{3} \mathrm{H}\right]$ AMPA binding to its high-affinity site, while noncompetitively enhancing binding to its lowaffinity site relative to control IgG preparations (open squares) or buffer (filled circles). Inset represents a Scatchard-Rosenthal plot of data from control and LP-BM5 IgG. B/F, bound/free.

the IgG preparation. LP-BM5 brain IgG (170-250 ng) eliminated $\left[{ }^{3} \mathrm{H}\right] \mathrm{AMPA}$ binding to its high-affinity site (buffer: $K_{\mathrm{d}} 120 \pm 4.0 \mathrm{nM}, B_{\max } 124 \pm 2 \mathrm{fmol} / \mathrm{mg}$ protein; control IgG: $K_{\mathrm{d}} 116 \pm 6.5 \mathrm{nM}, B_{\max } 133 \pm 4.9 \mathrm{fmol} / \mathrm{mg}$ protein; LP-BM5 IgG: not discriminated), while the density of the low-affinity binding site increased (buffer: $K_{\mathrm{d}} 2$ $250 \pm 31 \mathrm{nM}, B_{\max } 2240 \pm 33 \mathrm{fmol} / \mathrm{mg}$ protein, $n=4$; control IgG: $K_{\mathrm{d}} 2235 \pm 49 \mathrm{nM} ; B_{\max } 2280 \pm 26 \mathrm{fmol} / \mathrm{mg}$ protein, $n=6$; LP-BM5 IgG: $K_{\mathrm{d}} 230 \pm 39 \mathrm{nM}, B_{\max } 1,100 \pm 144$ $\mathrm{fmol} / \mathrm{mg}$ protein, $n=4$ ) (Figure $4 \mathrm{~b}$ ).

The immunoprecipitations (Figure 2d) indicated that LP-BM5 brain IgG interacted with other ionotropic glutamate receptors. This was supported by binding studies (Table 1) showing the suppression of $\left[{ }^{3} \mathrm{H}\right] \mathrm{KA}$ binding to KA receptors and $\left[{ }^{3} \mathrm{H}\right] \mathrm{CGS} 19755$ and $\left[{ }^{3} \mathrm{H}\right]$ MK-801 binding to the NMDA receptor by LPBM5 brain IgG preparations, albeit with 4- to 10-fold lower potency than the inhibition of $\left[{ }^{3} \mathrm{H}\right] \mathrm{AMPA}$ binding. In contrast, there was no evidence of IgG effect on $\left[{ }^{3} \mathrm{H}\right]$ nicotine binding to the nicotine receptor or $\left[{ }^{3} \mathrm{H}\right]$ flunitrazepam or $\left[{ }^{3} \mathrm{H}\right]$ muscimol binding the
$\mathrm{GABA}_{\mathrm{A}}$ receptor. IgG prepared from control mouse brain had no consistent effect on the binding of any of these radioligands.

Whole-cell clamping of hippocampal neurons revealed that LP-BM5 brain IgG could elicit currents. Applying 100 $\mu \mathrm{M}$ KA for 2 seconds evoked inward currents in hippocampal neurons (Figure 5a), with a peak amplitude of $3.1 \pm 0.4 \mathrm{nA}(n=30)$. While IgG preparations from uninfected mouse brains had no effect (Figure 5b), LP-BM5 brain $\operatorname{IgG}(3 \%$; Figure 5 c) activated inward currents in all neurons examined, but with a smaller peak current amplitude than KA $(590 \pm 84 \mathrm{pA}, n=24$, vs. $480 \pm 61 \mathrm{pA}, n=24$, respectively). In paired experiments, the $10-90 \%$ rise time for the KA-induced $(100 \mu \mathrm{M})$ current was $340 \pm 100 \mathrm{~ms}$, whereas the rise time for the IgG-induced (3\%) current was slower at $1,500 \pm 79 \mathrm{~ms}(P<0.0001$, paired $t$ test $n=21)$. Similarly, the time constant $(\tau)$ of a single exponential fit for current activation by IgG was slower than KA (KA: 135 \pm 39 ms; IgG: $645 \pm 65 \mathrm{~ms} ; P<0.0001$, paired $t$ test; $n=21$ ).

The sensitivity of the brain-derived IgG-evoked current to AMPA/KA-receptor antagonists was examined using the competitive antagonist 6-cyano-7-nitroquinoxaline-2,3-dione (CNQX; $50 \mu \mathrm{M})$. This compound inhibited KA-evoked $(100 \mu \mathrm{M})$ currents to $16 \pm 4 \%$ of control $(P<0.001 ; n=11)$ while reducing the IgG-elicited current amplitude to $67 \%$ of control ( $400 \pm 92$ to 260 $\pm 64 \mathrm{pA} ; P<0.001, n=5$; Figure 5 , $d$ and f). The noncompetitive, AMPA receptor-selective (18) antagonist 1(4-aminophenyl)-4-methyl-7,8-methylenedioxy-5H-2,3benzodiazepine (GYKI 52466) reduced the IgG-induced current to $56 \%(30 \mu \mathrm{M}: 350 \pm 39$ to $195 \pm 21 \mathrm{pA} ; P<0.01$, $n=6$; Figure $5 f)$ and $24 \%$ of control $(100 \mu \mathrm{M}: 450 \pm 160$ to $80 \pm 26 \mathrm{pA} ; P<0.05, n=4$, Figure 5 , e and $\mathrm{f}$ ).

Because AMPA-receptor activation by LP-BM5 IgG may negatively impact neuronal survival, IgG preparations were tested in primary cultures of cerebellar granule neurons. When cyclothiazide was added to block

Table 1

Inhibition of radioligand binding to ionotropic receptors by LP-BM5 IgG preparations

\begin{tabular}{|c|c|c|}
\hline Ligand & $\operatorname{lgG}$ source & $\begin{array}{c}\mathrm{IC}_{50} \\
(\mu \mathrm{g} \lg \mathrm{p} \text { protein/assay) }\end{array}$ \\
\hline$\left[{ }^{3} \mathrm{H}\right] \mathrm{AMPA}$ & $\begin{array}{l}\text { Control brain } \\
\text { Control serum } \\
\text { LP-BM5 brain } \\
\text { LP-BM5 serum } \\
\text { LP-BM5 brain, T-gel } \\
\text { LP-BM5 serum, T-gel }\end{array}$ & $\begin{array}{c}6.3 \pm 1.9 \\
4.8 \pm 2.2 \\
0.13 \pm 0.05 \\
0.80 \pm 0.39 \\
0.32 \pm 0.16 \\
0.56 \pm 0.11\end{array}$ \\
\hline$\left[{ }^{3} \mathrm{H}\right] \mathrm{CGS} 19755$ & $\begin{array}{l}\text { Control brain } \\
\text { LP-BM5 brain }\end{array}$ & $\begin{array}{c}\text { ND } \\
0.84 \pm 0.15\end{array}$ \\
\hline$\left[{ }^{3} \mathrm{H}\right] \mathrm{MK} 801$ & $\begin{array}{l}\text { Control brain } \\
\text { LP-BM5 brain }\end{array}$ & $\begin{array}{c}\text { ND } \\
1.27 \pm 0.60\end{array}$ \\
\hline$\left[{ }^{3} \mathrm{H}\right] \mathrm{MK}-801+\mathrm{gly} / \mathrm{glu}$ & $\begin{array}{l}\text { Control brain } \\
\text { LP-BM5 brain }\end{array}$ & $\begin{array}{c}\text { ND } \\
0.90 \pm 0.16\end{array}$ \\
\hline$\left[{ }^{3} \mathrm{H}\right]$ Kainic acid & $\begin{array}{l}\text { Control brain } \\
\text { LP-BM5 brain }\end{array}$ & $\begin{array}{c}\text { ND } \\
0.62 \pm 0.12\end{array}$ \\
\hline
\end{tabular}

Competition assays using IgG preparations from LP-BM5-infected and control mouse brains and serum were performed by preincubating the IgG preparation with well-washed membranes from the mouse cerebral cortex for 2 hours at $25^{\circ} \mathrm{C}$ before addition of radioligand. ND, no inhibition of radioligand binding was detected. 
Figure 5

LP-BM5 mouse brain IgG evokes inward currents in cultured hippocampal neurons. (a) Applying kainate (KA, $100 \mu \mathrm{M})$ to a neuron evokes a typical large and fast inward current. (c) Superfusing the same neuron with LP-BM5 brain IgG (3\% dilution in external recording solution, approximately $2.6 \mu \mathrm{g} \operatorname{lgG}$ protein/ml) evokes an inward current of smaller magnitude and slower onset than KA. (b) Control mouse brain IgG did not elicit a current. (d and f) CNQX (50 $\mu \mathrm{M})$ and (e and f) GYKI $52466(30,100 \mu \mathrm{M})$ reduced the LPBM5 brain IgG-activated current ( $\mathbf{d}$ and $\mathbf{f}$ ), consistent with its mediation by AMPA receptors. All data were collected in the continuous presence of TTX $(1 \mu \mathrm{M})$, d,I-APV $(100 \mu M)$, and strychnine $(1 \mu M)$. Significantly reduced compared with control: ${ }^{\mathrm{A}} P<0.05,{ }^{\mathrm{B}} P$ $<0.01$, and $C P<0.001$ (paired $t$ test, $n=6$ ).

AMPA receptor desensitization (21) and enhance neurotoxicity (22), AMPA released $\mathrm{LDH}$ from cultured granule neurons $\left(\mathrm{EC}_{50}\right.$ $1.8 \pm 0.2 \mu \mathrm{M}, n=4$; Figure $6 \mathrm{a}$ ), corresponding to the death of approximately $65 \%$ of all the neurons in the plate. AMPA-induced neurotoxicity was reduced $75 \%$ by coincubation with the competitive AMPA receptor-selective antagonist NBQX $(10 \mu \mathrm{M})$. Granule neurons exposed to LP-BM5 brain IgG were also damaged in a cyclothiazidedependent, NBQX-suppressible (neuron death decreased 64\%) fashion (ED $50130 \pm$ $21 \mathrm{ng} /$ well, $n=4$; Figure 6b). IgG from control mouse brains did not cause neuronal death at levels above those observed in the presence of cyclothiazide. Neuronal damage induced by LP-BM5 IgG was substantially increased in the presence of complement (IgG: $26 \pm 1.5 \%$ above control; $\mathrm{LDH}+$ complement serum: $200 \pm 28 \%$ above control; LDH + C4-deficient serum, $20 \pm 2.8 \%, n=4 ; P<0.05$, ANOVA), but was cyclothiazide independent.

Insights into the mechanism by which anti-AMPAreceptor Ab's were generated were provided by preadsorbing IgG preparations against virus proteins. Preparations of LP-BM5 brain and serum contained Ab's against both LP-BM5 MuLV components and, to a lesser extent, ecotropic virus, but not SC-1 cells (Figure 7a). Adsorbing IgG to LP-BM5 virus immobilized on PVDF membranes substantially diminished its subsequent ability to inhibit $\left[{ }^{3} \mathrm{H}\right]$ AMPA binding in three of four preparations tested $\left(\mathrm{IC}_{50}\right.$ : $67 \pm 13$ vs. $18 \pm 0.7 \mu \mathrm{l}$, with and without virus adsorption, respectively; $P<0.05, t$ test; Figure $7, \mathrm{~b}$ and c).

\section{Discussion}

LP-BM5 retrovirus-infected mice develop hypergammaglobulinemia and increased blood-brain barrier permeability, resulting in enhanced entry of IgG into the brain through the circumventricular organs and focal leaks (15), where it accumulates on neuron somas. Immunoprecipitations reveal interactions of LP-BM5 brain IgG
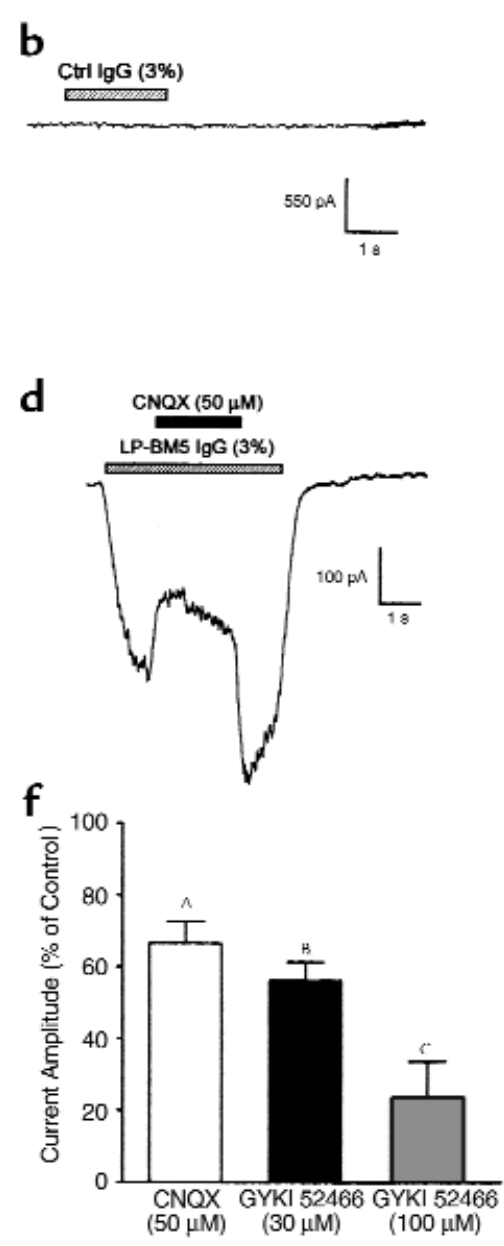

with ionotropic glutamate-receptor subunits, particularly GluR1 and 3, and to a lesser extent GluR2, 4, and NMDA receptor (NR1) subunits. The interaction of IgG with multiple subunits may reflect $\mathrm{Ab}$ production by multiple B-cell clones and/or shared epitopes between receptor subunits. Moreover, the interaction of brain IgG with GluR subunits has functional consequences, as indicated by the modulation of $\left[{ }^{3} \mathrm{H}\right]$ AMPA binding. This modulation was manifested as a decrease in the density of high-affinity and an increase in low-affinity binding sites. This effect is not a preparation artifact because it was eliminated by thermal denaturation, there was no detectable contamination of the preparations with glutamate, and IgG isolated using two different techniques altered $\left[{ }^{3} \mathrm{H}\right]$ AMPA binding. Brain IgG was a more potent modulator of $\left[{ }^{3} \mathrm{H}\right]$ AMPA binding than serum IgG preparations, consistent with the selective adsorption and concentration of serum IgG by brain proteins (23). The changes in $\left[{ }^{3} \mathrm{H}\right] \mathrm{AMPA}$ binding may reflect either the presence of multiple IgG clones varying in specificity for different AMPA receptor-binding sites or the interconversion of binding states forced by IgG interaction with an allosteric regulatory site (24).

Further evidence that the interaction of LP-BM5 brain IgG with AMPA receptors could impact receptor function was provided by electrophysiological studies of hippocampal pyramidal neurons. IgG preparations 
a

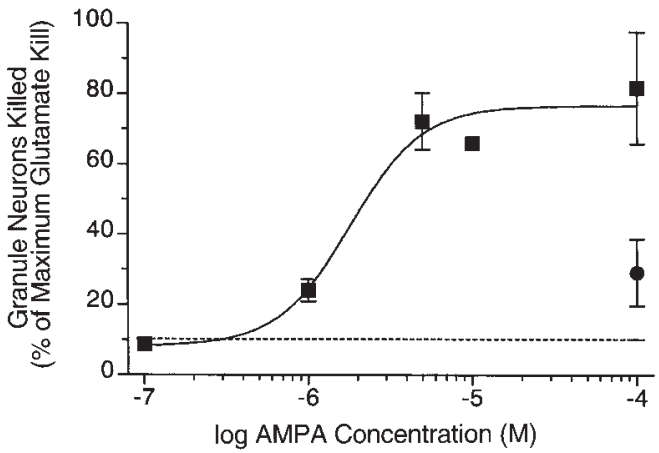

b

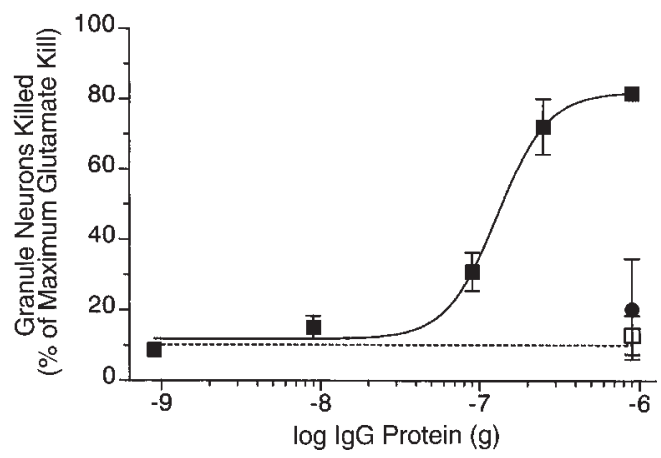

indicating that virus proteins and AMPA receptors have common epitopes. However, molecular mimicry of viral proteins may be insufficient to produce overt neuropathologies, because neither ecotropic virus-infected mice nor resistant mouse strains inoculated with LP-BM5 (26) yielded anti-AMPA Ab's. Furthermore, preadsorption of IgG to viral proteins did not eliminate activity from all IgG preparations tested. Concurrent immunopathologies, such as the loss of immune surveillance (27) and polyclonal B-cell activation by the def-gag superantigen (28), may be required for the production of high titers of antiAMPA Ab's during LP-BM5 infection. These mechanisms may also produce $A b$ 's that can interact with neuronal proteins other than AMPA receptors to alter synaptic

\section{a}

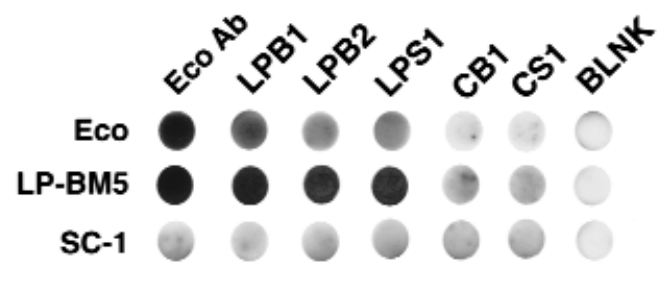

Figure 6

LP-BM5 brain IgG damages cerebellar granule neurons in vitro. In the absence of cyclothiazide ( $50 \mu \mathrm{M}), \mathrm{LDH}$ release into the medium (and associated neuron damage) did not exceed background levels (dashed line) after application of AMPA (a) or LP-BM5 brain IgG (b). AMPA or IgG in the presence of cyclothiazide dose dependently increased $\mathrm{LDH}$ release from granule neurons. The neurotoxicity induced by 100 $\mu \mathrm{M}$ AMPA or $900 \mathrm{ng} \lg \mathrm{G}$ was suppressed by $10 \mu \mathrm{M}$ NBQX (filled circles). IgG from control mouse brain in the presence of cyclothiazide (900 ng; open squares) did not increase neuronal damage above basal levels. MK-801 $(5 \mu \mathrm{M})$ was present in all experiments.

evoked currents from pyramidal neurons of lower amplitude and with slower opening kinetics than that observed with KA. Nonetheless, this activation was reversed by treatment with AMPA-receptor antagonists, consistent with the interaction of IgG preparations primarily with AMPA receptors. Allosteric modulation of AMPA-receptor function has been reported for anti-GluR3 Ab's in an animal model of Rasmussen's encephalitis (5), where the Ab recognizes a GluR3 subunit site distinct from the glutamate recognition site (25). The lesser degree of inhibition of brain IgGevoked currents by the competitive antagonist CNQX (19), the slow activation kinetics of the IgG-evoked current, and the saturation-binding data are all consistent with IgG binding to an allosteric modulatory site on the AMPA receptor to produce an inward current.

Unlike previous investigations where anti-AMPA-receptor Ab's were raised in response to immunizations with fusion proteins derived from GluR3 subunit fragments (5, 8), the present results indicate that anti-AMPA receptor $\mathrm{Ab}$ 's can be produced in association with a virus-induced immunopathology. This conclusion is supported by the suppression of IgG interaction with AMPA receptors following exposure to immobilized LP-BM5 virus proteins,

b

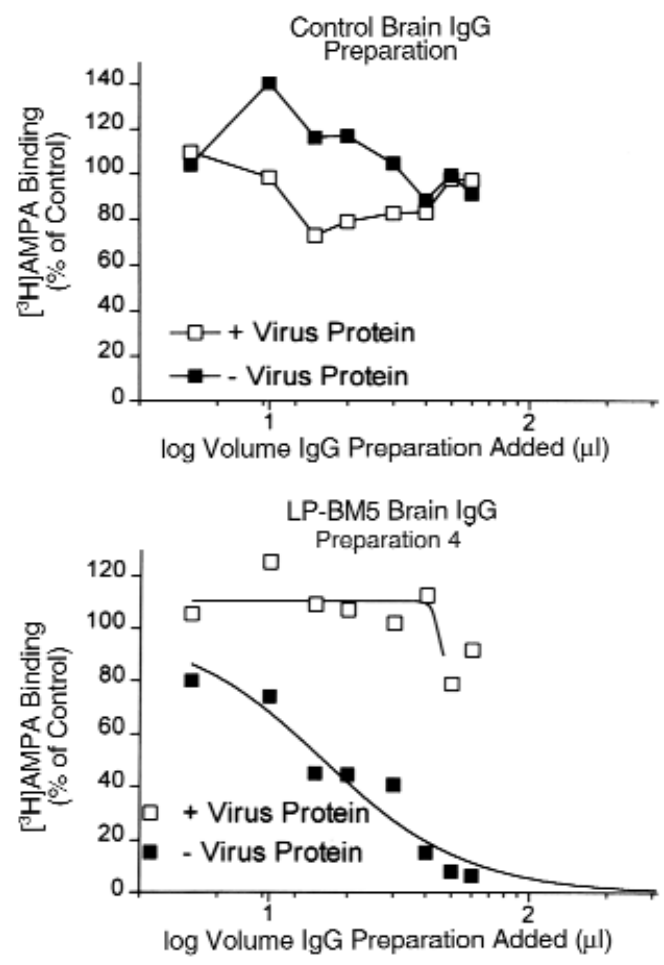

Figure 7

Preadsorbing $\lg G$ against immobilized LP-BM5 virus preparations reduces its ability to inhibit $\left[{ }^{3} \mathrm{H}\right]$ AMPA binding. (a) Ecotropic (Eco) virus, or LPBM5 virus, or SC-1 parent cells were immobilized on PVDF membranes and incubated with $A b$ to ecotropic virus gag protein (Eco Ab) or IgG preparations from LP-BM5 brain (LPB), LP-BM5 serum (LPS), control brain (CB), control serum (CS), or PBS (BLNK). Infected, but not uninfected, mouse preparations contained IgG to LP-BM5 virus. Incubating PVDF strips treated with LP-BM5 virus protein with infected mouse IgG (b) (open squares) decreased its ability to inhibit [ $\left.{ }^{3} \mathrm{H}\right] \mathrm{AMPA}$ binding compared with strips treated with blocking agent only (filled squares) (c). 
transmission, as evidenced by the presence of Ab's to other AMPA receptor and NMDA-receptor subunits. Similar mechanisms may also be present in Rasmussen's encephalitis, where Ab's to the synaptic protein munc-18, as well as GluR3, have been described recently (29).

The electrophysiological studies and in vitro cytotoxicity assays indicate that LP-BM5 IgG preparations can chronically activate AMPA receptors to depolarize neurons, causing excitotoxic damage. The ability of several AMPA-receptor antagonists to block these currents and suppress neuronal damage in vitro, coupled with previous observations that AMPA antagonists inhibit dendritic damage in LP-BM5-infected mice in vivo (13), imply that these antagonists may constitute an effective treatment modality for neurological syndromes caused by anti-AMPA-receptor Ab's, such as Rasmussen's encephalitis. However, the extent of this protection is unclear. IgGinduced AMPA receptor-mediated neurotoxicity depended upon cyclothiazide to inactivate desensitization mechanisms (21), while sublethal titers of IgG became neurotoxic in the presence of complement. These results suggest that extensive neuronal death in vivo might require complement fixation and would not be responsive to treatment with AMPA-receptor antagonists.

The present study provides strong evidence that a virus infection produces Ab's that can activate the AMPA receptor and may contribute to excitotoxic brain damage. Moreover, the deleterious actions of these Ab's in vitro are mitigated by AMPA-receptor antagonists, which may be useful in the treatment of patients with autoimmune diseases involving the AMPA receptor. The prevalence of such disorders is currently unknown, but given that LPBM5-infected mice develop a profound immunodeficiency in addition to their neuropathologies, anti-AMPAreceptor Ab's may be involved in neurodegenerative diseases other than Rasmussen's encephalitis, such as HIV-associated dementia complex (30). Patients infected with HIV-1 commonly develop a hypergammaglobulinemia with immunoglobulin accumulation in the CNS (31). Subsets of these patients also show decreased GluRA flop mRNA (32), synapse loss, myelin pallor (30), and evidence of excitotoxic neuronal damage (33). Ab's to brain proteins are present in many of these patients (34), but are incompletely characterized, opening the possibility that anti-AMPA-receptor Ab's may be involved in the development of a wider variety of chronic neurodegenerative disorders than suspected previously.

\section{Acknowledgments}

We would like to thank R. Wenthold and P. Seeburg for the plasmids containing GluR1-4 sequences and $\mathrm{H}$. C. Morse, III for the anti-ecotropic virus gag Ab.

\footnotetext{
1. Lindstrom, J., Shelton D., and Fuji, Y. 1988. Myasthenia gravis. Adv. Immunol. 42:233-284.

2. Martin, R., and McFarland, H. 1995. Immunological aspects of experimental allergic encephalomyelitis and multiple sclerosis. Crit. Rev. Clin. Lab. Sci. 32:121-182.

3. Lang, B., and Vincent, A. 1996. Autoimmunity to ion-channels and other proteins in paraneoplastic disorders. Curr. Opin. Immunol. 8:865-871. 4. Posner, J.B., and Dalmau, J.O. 1997. Paraneoplastic syndromes affecting
}

the central nervous system. Annu. Rev. Med. 48:157-166.

5. Rogers, S.W., et al. 1994. Autoantibodies to glutamate receptor GluR3 in Rasmussen's encephalitis. Science. 265:648-651.

6. Gahring, L.C., Rogers, S.W., and Twyman, R.E. 1997. Antibodies to glutamate receptor subunit GluR2 in nonfamilial olivopontocerebellar degeneration. Neurology. 48:494-500.

7. Hollman, M., and Heinemann, S. 1994. Cloned glutamate receptors. Annu. Rev. Neurosci. 17:31-108.

8. Whitney, K.D., and McNamara, J.O. 1999. Autoimmunity and neurological disease: antibody modulation of synaptic transmission. Annu. Rev. Neurosci. 22:175-195.

9. Oldstone, M.B.A. 1987. Molecular mimicry and autoimmune disease. Cell. 50:819-820.

10. Renno, T., and Acha-Orbea, H. 1996. Superantigens in autoimmune diseases: still more shades of gray. Immunol. Rev. 154:175-191.

11. Espey, M.G, Kustova, Y., Sei, Y., and Basile, A.S. 1998. The LP-BM5 murine leukemia virus: impact on the immune and central nervous systems. In Neuroimmunodegeneration. P.K.Y. Wong and W. Lynn, editors. Springer Verlag. Berlin, Germany. 95-114.

12. Sei, Y., Arora, P.K., Skolnick, P., and Paul, I.A. 1992. Spatial learning impairment in a murine model of AIDS. FASEB J. 6:30008-30013.

13. Kustova, Y., Sung, E.-G., Morse, D., Sei, Y., and Basile, A.S. 1999. Histological evidence of neuronal degeneration in mice infected with the LPBM5 murine leukemia virus. Mol. Chem. Neuropathol. 35:39-59.

14. Kustova, Y., Ha, J.-H., Espey, M., Sei, Y., and Basile, A.S. 1998. The pattern of neurotransmitter alterations in LP-BM5 infected mice are consistent with glutamatergic hyperactivation. Brain Res. 793:119-126.

15. Kustova, Y., Espey, M.G., Sei, Y., and Basile, A.S. 1997. Regional decreases in AMPA receptor density in mice infected with the LP-BM5 murine leukemia virus. Neuroreport. 8:1243-1247.

16. Kustova, Y., Grinberg, A., and Basile, A.S. 1999. Increased blood-brain barrier permeability in LP-BM5 infected mice is mediated by neuroexcitatory mechanisms. Brain Res. 839:153-163.

17. Espey, M.G., Kustova, Y., Sei, Y., and Basile, A.S. 1998. Extracellular glutamate levels are elevated in the brains of LP-BM5 infected mice: relevance to retrovirus associated encephalopathies. J. Neurochem. 71:2079-2087.

18. Donevan, S.D., and Rogawski, M.A. 1993. GYKI 52466, a 2,3-benzodiazepine, is a highly selective noncompetitive antagonist of AMPA/Kainate receptor responses. Neuron. 10:51-59.

19. Rho, J.M., Donevan, S.D., and Rogawski, M.A. 1997. Direct activation of $\mathrm{GABA}_{\mathrm{A}}$ receptors by barbiturates in cultured rat hippocampal neurons. J. Physiol. (Lond.) 497:509-522.

20. Fossom, L.H., Basile, A.S., and Skolnick, P. 1995. Sustained exposure to 1-aminocyclopropanecarboxylic acid, a glycine partial agonist, alters $\mathrm{N}$ methyl-D-aspartate receptor function and subunit composition. Mol. Pharmacol. 48:981-987.

21. Partin, K.M., Patneau, D.K., Winters, C.A., Mayer, M.L., and Buonanno, A. 1993. Selective modulation of desensitization at AMPA versus kainate receptors by cyclothiazide and concanavalin A. Neuron. 11:1069-1082.

22. Hack, N., and Balazs, R. 1995. Properties of AMPA receptors expressed in rat cerebellar granule cell cultures: $\mathrm{Ca}^{2+}$ influx studies. J. Neurochem. 65:1077-1084.

23. VonHerrath, M.G., and Oldstone, M.B.A. 1996. Virus-induced autoimmune disease. Curr. Opin. Immunol. 8:878-885.

24. Honore, T., and Drejer, J. 1988. Chaotropic ions affect the conformation of quisqualate receptors in rat cortical membranes. J. Neurochem. 51:457-461.

25. Stern-Bach, Y., et al. 1994. Agonist selectivity of glutamate receptors is specified by two domains structurally related to bacterial amino acidbinding proteins. Neuron. 13:1345-1357.

26. Hartley, J.W., Fredrickson, T.N., Yetter, R.A., Makino, M., and Morse, H.C., III. 1989. Retrovirus-induced murine acquired immunodeficiency syndrome: natural history of infection and differing susceptibility of inbred mouse strains. J. Virol. 63:1223-1231.

27. Suzuki, K., et al. 1993. Exocrinopathy resembling Sjogren's syndrome induced by a murine retrovirus. Lab. Invest. 69:430-435.

28. Kanagawa, O., Wiebenga, M.E., and Vaupel, B.A. 1993. Defective T cell receptor-mediated signaling and differential induction of $\mathrm{T}$ cell functions by murine AIDS virus superantigen. J. Immunol. 150:1865-1872.

29. Yang, R., et al. 2000. Autoimmunity to Munc-18 in Rasmussen's encephalitis. Neuron. 28:375-383.

30. Spencer, D.C., and Price, R.W. 1992. Human immunodeficiency virus and the central nervous system. Annu. Rev. Microbiol. 46:655-693.

31. Petito, C.K., and Cash, K.S. 1992. Blood-brain barrier abnormalities in the acquired immunodeficiency syndrome: immunohistochemical localization of serum proteins in postmortem brain. Ann. Neurol. 32:658-666.

32. Everall, I.P., et al. 1995. Decreased expression of AMPA receptor messenger RNA and protein in AIDS: a model for HIV-associated neurotoxicity. Nat. Med. 1:1174-1178.

33. Lipton, S.A., and Gendelman, H.E. 1995. Dementia associated with the acquired immunodeficiency syndrome. N. Engl. J. Med. 332:934-940.

34. Trujillo, J.R., et al. 1994. Evaluation of autoantibodies to brain proteins in patients with AIDS dementia complex. J. AIDS. 7:103-108. 